DOI: $10.36910 / 6775-2524-0560-2020-38-04$

UDC: $004.93 .1 ; 681.142$

1,2Заяць Василь Михайлович, д.т.н., професор;

https://orcid.org/0000-0001-7150-1070

${ }^{3}$ Рибицька Ольга Мар'янівна., к.ф-мат.н., доцент;

https://orcid.org/0000-0002-2394-355X

${ }^{1}$ Маєвський Яцек, $\mathrm{PhD}$, доцент;

https://orcid.org/0000-0001-7715-6415

${ }^{1}$ Марціняк Томаш, $\mathrm{PhD}$, доцент;

https://orcid.org/0000-0003-1801-1624

Заяць Марія Михайлівна, старший викладач. https://orcid.org/0000-0002-9015-0138

${ }^{1}$ Університет Технологічно-Природничий (UTP), м. Бидгощ, Польща.

${ }^{2}$ Національний університету водного господарства та природокористування, м. Рівне, Україна.

${ }^{3} \mathrm{HУ} \mathrm{“Львівська} \mathrm{політехніка”,} \mathrm{м.} \mathrm{Львів,} \mathrm{Україна.}$

\title{
METHODS OF FUZZY SETS THEORY FOR STATISTICAL ANALYSIS OF MASS SERVICE SYSTEMS
}

\begin{abstract}
Zaiats V.M., Rybytska O.M., Majewski J., Marciniak T., Zaiats M.M. Methods of fuzzy sets theory for statistical analysis of mass service systems. Approaches to the processing of fuzzy information are proposed in the conditions of incomplete determination of the vector of input characteristics, which are based on the theory of fuzzy sets and fuzzy measures. Their analysis have been carried out, the limits of their use, and areas of effective application, in particular, regarding mass service systems.

Keywords: fuzzy sets, fuzzy logic, measures theory, systems of mass service, methods of pattern recognition theory, logical and functional programming.

Заяць В.М., Рибицька О.М., Маєвський Я., Марціняк Т., Заяць М.М. Методи теорії нечітких множин для аналізу систем масового обслуговування. Запропоновано підходи до обробки нечіткої інформації в умовах неповного визначення вектора вхідних характеристик, які базуються на теорії нечітких множин та нечітких мір. Проведено їх аналіз, визначено межі їх використання та сфери ефективного застосування, зокрема, щодо систем масового обслуговування.
\end{abstract}

Ключові слова: нечіткі множини; нечітка логіка; теорія мір; методи теорії розпізнавання; системи масового обслуговування, логічне і функціональне програмування.

Заяць В.М., Рибицька О.М., Маевский Я., Марциняк Т., Заяць М.М. Методы теории нечетких множеств для анализа систем массового обслуживания. Предложены подходы к обработке нечеткой информации в условиях неполного определения вектора входных характеристик, основанные на теории нечетких множеств и нечетких мер. Проведен их анализ, определены границы их использования и сферы эффективного применения, в частности, касательно систем массового обслуживания.

Ключевые слова: нечеткие множества; нечеткая логика; теория мер; методы теории распознавания; системы массового обслуживания, логическое и функциональное программирование.

I. Introduction. The significance of theoretical results, as a rule, is based on their practical value in applied applications that directly or indirectly confirm the feasibility of their application and do not violate the logic of reasoning. Newly introduced terms or analytical or descriptive formulas that are not operational and do not have practical value over time are excluded from scientific consideration.

The purpose of the work is to show the universality of the approach to statistical analysis of the value of information fuzzy on the basis of the theory of images and fuzzy logic, to compare it with existing methods and approaches to assessing the value of information, to indicate the limits of practical applications, to determine the advantages and disadvantages, the directions of further research.

II. The approach based on the fuzzy sets and measures theory. The aforementioned disadvantages are eliminated in the approach based on the application of methods of recognition theory and operates with the notion of information, the quantity and value of information that are different from the classical definitions obtained on the basis of probability theory.

The problems of mathematical and computer modeling today lie, in particular, in the impossibility of applying precise logic rules and models of tasks with clearly defined input parameters in cases where, for some reason, there are contradictions, uncertainties or uncertainties of information about the object being studied, system or phenomenon [1]. 
Uncertainty is known to arise due to a lack of knowledge relating to a specific event [10]. She is present to the experiment. The mathematical model of uncertainty is based on the theory of probabilities, the theory of possibilities, confidence measures, theory calculate of predictions and functions, and a number of others.

The phenomenon of fuzziness arises in the process of combining into one whole objects that have a common property $\varphi$ :

$$
\mathrm{X}=\{\mathrm{x} \mid x \text { owns } \varphi\}
$$

where $x$ all the elements of a certain universal set run.

Given that there are always elements $x$ in the reality that it is unclear whether they possess the specified property or not, $X$ it is not a plural in the classical sense. Any attempt to interpret the general description leads to fuzzy concepts, since the exact description contains an excess of details. Increasing the accuracy of the description leads to an increase in the amount of information, the content of which decreases until the time when the accuracy and meaningfulness do not become mutually exclusive. For the first time, LA stressed the need for uncertainty for the transmission of content Zade [5]. It was the ideas of this American scientist who pushed for the development of "fuzzy mathematics" [6], which, along with the apparatus of fuzzy sets, contains other methods of work with uncertainty.

The application of the theory of fuzzy sets and measures is a step towards the convergence of the precision of classical mathematics with a false inaccuracy of the environment, an attempt to overcome the linguistic barrier between a person whose judgment and evaluation are approximate and fuzzy, and technical means which can only carry out precise instructions [7].

A device that allows you to work with fuzzy logic, "blurred" parameters of models, is a Fuzzytechnology device. The Fuzzy-Technology division has fuzzy expert systems.

Linguistic (descriptive) variables extend the ability to represent knowledge. They are determined by fuzzy sets whose values are established by membership functions. Membership functions can be obtained through subjective expert assessments [8], or by analyzing fuzzy clusters. According to [8], fuzzy expert systems can be implemented when the cost of acquiring accurate information, that is, information in absolute terms, exceeds the maximum revenue from the restructuring of a model or is virtually impossible.

It is known that the initial stage of constructing artificial intelligence on the basis of the use of natural language is based on ambiguous logic and the mechanism of output with rigid rules.

The modern or second generation of expert systems possesses at least two peculiarities: fuzzy presentation of knowledge and fuzzy deductions. One of the most common problems of logical derivation in the conditions of fuzziness can be formulated as follows:

\section{Given ( fuzzy) log ical rule" If A, then $B "$. \\ Observed $A^{\prime}$ (A to some extent). What should be B?}

After receiving the fuzzy set of conclusions, find a specific numerical match (conduct dephasing).

Consider the object with one output and $n$ inputs of the form

$$
y=f\left(x_{1}, x_{2}, \ldots, x_{n}\right)
$$

where the set of values $x_{1}, \ldots, x_{n}$-of input variables; $y$ - output variable.

To construct a mathematical model on the basis of establishing the relationship between input and output variables in accordance with experimental data, by conducting a phasing operation, quantitative and qualitative variables are translated into linguistic terms

$$
\begin{aligned}
U_{i} & =\left[\underline{u_{i}}, \overline{u_{i}}\right], \quad i=\overline{1, n}, \\
Y & =[\underline{y}, \bar{y}],
\end{aligned}
$$


where $\underline{u_{i}}, \overline{u_{i}}$ - the smallest and the highest possible value of the variable $x_{i} ; \quad \underline{y}, \bar{y}$ - the smallest and the highest possible value of the output variable $y$.

To solve the problem (8), it is necessary to apply a method of making a decision by which the fixed vector of input variables $x^{*}=\left(x_{1}^{*}, x_{2}^{*}, \ldots, x_{n}^{*}\right), x_{i}^{*} \in U_{i}$ would unambiguously be placed in accordance with the solution $y^{*} \in Y$. For the formal establishment of this dependence we shall consider the input $x_{i}, i=\overline{1, n}$ and output $y$ parameters as linguistic variables given on universal sets (9), (10). To evaluate linguistic variables $x_{i}, i=\overline{1, n}$ and $y$, we will use qualitative terms from the following term sets:

$A_{i}=\left\{a_{i}^{1}, a_{i}^{2}, \ldots, a_{i}^{p_{i}}\right\}$-term-set of input variable $x_{i}, i=\overline{1, n} ; \quad D=\left\{d_{1}, d_{2}, \ldots, d_{m}\right\}-$ term set of output variable $y$. To construct term sets it is possible to apply, for example, the method proposed in [7].

For each term of each linguistic variable, based on expert knowledge, the memberships functions $\mu^{a_{i}^{p}}(x)$ and $\mu^{d_{j}}(y)$ (trapezoidal, triangular, rectangular, sinusoidal, parabolic, etc.) [7] are constructed based on expert knowledge, where $\mu^{a_{i}^{p}}(x)$ - the degree of belonging of the element $x \in U_{i}$ to the term $a_{i}^{p} \in A_{i}, \quad i=\overline{1, n} ; \quad p=\overline{1, p_{i}} ; \quad \mu^{d_{j}}(y)-$ the degree of belonging of the element $y \in Y$ to the term $d_{j} \in D, j=\overline{1, m}$.

The definition of linguistic estimates of variables and the membership functions necessary for their formalization is the first stage in the construction of a fuzzy model of the object being studied. In the literature on fuzzy logic, he received the name of the fuzzification of variables [10].

The next step is to create a fuzzy knowledge base.

Let the object (1) know the rules that connect its inputs and output using vectors such as:

$$
V_{k}=\left(x_{1}, x_{2}, \ldots, x_{n}, y\right), k=\overline{1, N}, \text { else } N=k_{1}+\ldots+k_{j}+\ldots+k_{m},
$$

where $k_{j}$ - the number of experimental data corresponding to the same value $d_{j}$ of the term-set of the output variable $y ; m$ - the total number of terms of the output variable, and in the general case $k_{1} \neq \ldots \neq k_{m}$.

We will assume that the number $N<p_{1} p_{2} \ldots p_{n}$, of available experimental data is less than the total overview of various combinations of possible terms of input variables $p_{i}, i=\overline{1, n}$. Then the knowledge base is a table formed according to the following rules:

1. The table's size is equal $N \times(n+2)$, where $n+2-$ number of columns and $N$ - the number of rows;

2. Each line of the matrix is a combination of input variables assigned by the expert to one of the possible values of the term-set of the output variable $y$. In this case, the first $k_{1}$ lines correspond to the value of the output variable $y=d_{1}$, the following $k_{2}$ lines - to the value $y=d_{2}$, etc., and the last $k_{m}$ lines - to the value $y=d_{m}$;

3. The first $n$ columns of the matrix correspond to the input variables $x_{i}, i=\overline{1, n}$; the $(n+1)$-th the weight $W_{j p}, j=\overline{1, m}, p=\overline{1, k_{j}}$, of the rule and $(n+2)$-th - the value to the output term-set $d_{j}$ of the variable $y, j=\overline{1, m}$, corresponding to the combination of values in the first $(n+1)-$ th columns.

4. The element $a_{i}^{j p}$, located at the intersection of the $i$-th column and the $j_{P}$-line corresponds to the linguistic evaluation of the parameter $x_{i}$ in the row of knowledge matrix with the number $j_{P}$. In this case, the linguistic assessment $a_{i}^{j p}$ is chosen with the term-set corresponding to the variable $x_{i}$, i.e. $a_{i}^{j p} \in A_{i}, i=\overline{1, n} ; j=\overline{1, m} ; p=\overline{1, k_{j}}$. 
When an expert creates linguistic rules such as "IF - THEN" that form the basis of fuzzy knowledge about a particular object, the expert's confidence in each rule may be different. If one rule in the opinion of an expert can serve as an undeniable truth, then according to another rule in the same expert there may be some doubts.

In order to reflect these different degrees of confidence in the base of fuzzy knowledge, the weighting of the rules is introduced - these are numbers from the interval $[0,1]$ that characterize the expert's confidence in each particular rule chosen by him to make a decision. The general view of the knowledge base is given in Table. 1 .

Table 1 . General view of the fuzzy knowledge base

\begin{tabular}{|c|c|c|c|c|c|c|}
\hline \multirow{2}{*}{$\begin{array}{c}\text { Incoming } \\
\text { combination number }\end{array}$} & \multicolumn{4}{|c|}{ Input variables } & \multirow{2}{*}{\begin{tabular}{|r} 
Weight \\
$w$
\end{tabular}} & \multirow{2}{*}{$\begin{array}{r}\begin{array}{c}\text { Output } \\
\text { variables }\end{array} \\
y\end{array}$} \\
\hline & $x_{1}$ & $x_{2}$ & $\ldots x_{i} \ldots$ & $x_{n}$ & & \\
\hline 11 & $a_{1}^{11}$ & $a_{2}^{11}$ & $a_{i}^{11}$ & $a_{n}^{11}$ & $w_{11}$ & \multirow{4}{*}{$d_{1}$} \\
\hline 12 & $a_{1}^{12}$ & $a_{2}^{12}$ & $a_{i}^{12}$ & $a_{n}^{12}$ & $w_{12}$ & \\
\hline$\ldots$ & $\ldots$ & $\cdots$ & $\ldots$ & $\ldots$ & $\ldots$ & \\
\hline $1 k_{1}$ & $a_{1}^{1 k_{1}}$ & $d_{2}^{1 k_{1}}$ & $a_{i}^{1 k_{1}}$ & $a_{n}^{1 k_{1}}$ & $w_{1 k_{1}}$ & \\
\hline$\cdots$ & $\cdots$ & $\cdots$ & $\cdots$ & $\cdots$ & $\cdots$ & $\ldots$ \\
\hline$j_{1}$ & $a_{1}^{j 1}$ & $a_{2}^{j 1}$ & $a_{i}^{j 1}$ & $a_{n}^{j 1}$ & $w_{j 1}$ & \multirow{4}{*}{$d_{j}$} \\
\hline$j_{2}$ & $a_{1}^{j 2}$ & $a_{2}^{j 2}$ & $a_{i}^{j 2}$ & $a_{n}^{j 2}$ & $w_{j 2}$ & \\
\hline$\ldots$ & $\ldots$ & $\cdots$ & $\ldots$ & $\cdots$ & $\ldots$ & \\
\hline$j k_{j}$ & $a_{1}^{j k_{j}}$ & $\oiint_{2}^{j k_{j}}$ & $a_{i}^{j k_{j}}$ & $a_{n}^{j k_{j}}$ & $w_{j k_{j}}$ & \\
\hline$\cdots$ & $\cdots$ & $\cdots$ & $\cdots$ & $\cdots$ & $\ldots$ & $\ldots$ \\
\hline$m_{1}$ & $a_{1}^{m 1}$ & $a_{2}^{m 1}$ & $a_{i}^{m 1}$ & $a_{n}^{m 1}$ & $w_{m 1}$ & \multirow{4}{*}{$d_{m}$} \\
\hline$m_{2}$ & $a_{1}^{m 2}$ & $d_{2}^{m 2}$ & $a_{i}^{m 2}$ & $a_{n}^{m 2}$ & $w_{m 2}$ & \\
\hline$\cdots$ & $\cdots$ & $\cdot$. & $\cdots$ & $\cdots$ & $\cdots$ & \\
\hline$m k_{m}$ & $a_{1}^{m k_{m}}$ & $a_{2}^{m k_{m}}$ & $a_{i}^{m k_{m}}$ & $a_{n}^{m k_{m}}$ & $w_{m k_{m}}$ & \\
\hline
\end{tabular}

After building the knowledge base, you need to carefully check in Table 1 the presence of the opposite in the content of the lines, that is, rules that the same input variables have different output values. The introduced matrix of knowledge defines a system of logical utterances such as "IF - THEN, ELSE", which associate the values $x_{1}, \ldots, x_{n}$ of input variables with one of the possible output values $d_{j}, j=\overline{1, m}$ :

$$
\begin{aligned}
& \text { IF }\left(x_{1}=a_{1}^{11}\right) \text { AND }\left(x_{2}=a_{2}^{11}\right) \text { AND } \ldots \text { AND }\left(x_{n}=a_{n}^{11}\right)\left(\text { with weight } w_{11}\right), \\
& \text { OR }\left(x_{1}=a_{1}^{12}\right) \text { AND }\left(x_{2}=a_{2}^{12}\right) \text { AND } \ldots \text { AND }\left(x_{n}=a_{n}^{12}\right)\left(\text { with weight } w_{12}\right), \\
& \text { OR } \ldots
\end{aligned}
$$




$$
\begin{aligned}
& \text { OR }\left(x_{1}=a_{1}^{1 k_{1}}\right) \text { AND }\left(x_{2}=a_{2}^{1 k_{1}}\right) \text { AND } \ldots \text { AND }\left(x_{n}=a_{n}^{1 k_{1}}\right)\left(\text { with weight } w_{1 k_{1}}\right), \\
& \text { THEN } y=d_{1} \text {, OTHERWISE } \\
& \text { IF } \left.\left(x_{1}=a_{1}^{21}\right) \text { AND }\left(x_{2}=a_{2}^{21}\right) \text { AND } \ldots \text { AND }\left(x_{n}=a_{n}^{21}\right) \text { (with weight } w_{21}\right), \\
& \text { OR } \ldots
\end{aligned}
$$

OR $\left(x_{1}=a_{1}^{2 k_{2}}\right)$ AND $\left(x_{2}=a_{2}^{2 k_{2}}\right)$ AND $\ldots$ AND $\left(x_{n}=a_{n}^{2 k_{2}}\right)$ (with weight $\left.w_{2 k_{2}}\right)$,

THEN $y=d_{2}$, OTHERWISE ...

$$
\text { IF } \left.\left(x_{1}=a_{1}^{m 1}\right) \text { AND }\left(x_{2}=a_{2}^{m 1}\right) \text { AND } \ldots \text { AND }\left(x_{n}=a_{n}^{m 1}\right) \text { (with weight } w_{m 1}\right),
$$

OR ...

OR $\left(x_{1}=a_{1}^{m k_{m}}\right)$ AND $\left(x_{2}=a_{2}^{m k_{m}}\right)$ AND ... AND $\left(x_{n}=a_{n}^{m k_{m}}\right)$ (with weight $\left.w_{m k_{m}}\right)$,

THEN $y=d_{m}$.

A similar system of logical expressions is called a fuzzy knowledge base. Using the operations (OR) and (AND) described system of logical statements can be rewritten in a more compact form:

$$
\bigcup_{p=1}^{k_{j}}\left[\bigcap_{i=1}^{n}\left(x_{i}=a_{i}^{j p}\right)\right] \rightarrow y=d_{j}, j=\overline{1, m} .
$$

Thus, the input relation (1), which establishes the connection between the input parameters $x_{i}, i=\overline{1, n}$ and the output variable, is formalized in the form of a system of fuzzy logical statements (5) based on the created matrix of knowledge. The rules of the described fuzzy system, in which the degree of truth is different from zero, is considered to be active.

In [7], a method is proposed to use fuzzy logic equations that are based on a knowledge matrix or isomorphic system of logical expressions (5) and allow us to calculate the values of the membership functions of the output variable for the fixed values of the inputs of the object.

Linguistic estimates $a_{i}^{j p}$ of the variables $x_{1}, \ldots x_{n}$, contained in the logical statements (5) will be considered as fuzzy sets defined on universal sets (3). We introduce the following notation:

$\mu^{a_{i}^{j p}}\left(x_{i}\right)$ - the membership function of the parameter $x_{i}$ to the fuzzy term $a_{i}^{j p}, i=\overline{1, n}, j=\overline{1, m}, p=\overline{1, k_{j}} ; \mu^{d_{j}}\left(x_{1}, x_{2}, \ldots x_{n}\right)$ - membership function of the vector of the input variables $x=\left(x_{1}, x_{2}, \ldots x_{n}\right)$ of the term of the output variable $y=d_{j}, j=\overline{1, m}$.

Thus, we have two types of functions, the relationship between which is determined by the base of fuzzy knowledge (5), on the basis of which you can output a system of logical equations, which can be submitted in a compact form:

$$
\mu^{d_{j}}\left(x_{1}, x_{2}, \ldots, x_{n}\right)=\underset{p=1}{k_{j}}\left(w_{j p}\left[\hat{i=1}^{n} \mu^{a_{i}^{j p}}\left(x_{i}\right)\right]\right), j=\overline{1 . m}
$$

where $\vee-$ is the logical "OR"; $\wedge$ - logical "AND".

The decision $d^{*} \in D\left\{d_{1}, d_{2}, \ldots, d_{m}\right\}$, that corresponds to a fixed vector of the values of input variables $x^{*}=\left(x_{1}^{*}, x_{2}^{*}, \ldots, x_{n}^{*}\right)$ will be carried out in accordance with the following algorithm constructed using the apparatus of the fuzzy (blurry) logic [9]:

1. The possible range of change of controlled parameters is determined, a knowledge base is created with the use of expert data and a system of fuzzy logic equations is derived (6).

2. The vector of the values of the input variables $x^{*}=\left(x_{1}^{*}, x_{2}^{*}, \ldots, x_{n}^{*}\right)$ is fixed.

3. Specifies the function of fuzzy term membership for different controlled parameters. 
4. Using logical equations (6), the values of many parametric membership functions $\mu^{d_{j}}\left(x_{1}^{*}, x_{2}^{*}, \ldots, x_{n}^{*}\right)$ of vector $X$ for all values $d_{j}, j=\overline{1, m}$ of the output variable $y$. are calculated. In this case, the logical operations $\vee(\mathbf{O R})$ and $\wedge$ (AND) over the membership functions are replaced by the operations $\max$ and $\min$ :

$$
\begin{aligned}
& \mu(a) \vee \mu(b)=\max [\mu(a), \mu(b)], \\
& \mu(a) \vee \mu(b)=\max [\mu(a), \mu(b)],
\end{aligned}
$$

That is, first find the minimum values of belonging functions in each rule, and then among them they choose the highest value of the membership function among all rules for each value $d_{j}, j=\overline{1, m}$, which corresponds to the original variable $y$. Thus, the conclusion is made that the origin variable $y$ belongs to a term $d_{j}^{*}$, whose membership function is maximal.

The proposed algorithm uses the idea of identifying the linguistic term by the maximum of membership function and generalizes this approach to the entire knowledge matrix. The computational part of this algorithm is easily realized by simply applying operations $\mathbf{m a x}$ and $\mathbf{m i n}$.

To obtain a clear number from an interval $[\underline{y}, \bar{y}]$ that corresponds to a fuzzy value of the output variable, it is necessary to apply a dephasing operation. You can define this clear number, for example, by the gravity method

$$
y^{*}=\frac{\int_{\operatorname{Min}}^{\operatorname{Max}} y \mu(y) d y}{\int_{\operatorname{Min}}^{\operatorname{Max}} \mu(y) d y},
$$

where Min and Max is the left and right points of the interval of the fuzzy set of the source variable $y$.

II. Results of statistical analysis on an example of a system of mass service. The task of forecasting the value of unrealized goods of a certain type at the end of the trade season of a trading firm dealing with chemical protection products of plants is considered in the paper. Obviously, minimizing the balance from unrealized goods will increase the efficiency (productivity) of the trading firm.

The experts found that the weighting factors that affect the current balance $Y$ are: $x_{1}$ ("balance") the balance of the previous trading season (in US dollars); $x_{2}$ - "New purchases") - the cost of new purchases (in US dollars); $x_{3}$ ("Margin") - the average value of trade margins (in percentages); $x_{4}$ ("the duration ") - the duration of the sale of this drug (in years). The universal sets for the described variables are defined as follows: $U_{1}=[0 ; 600000] ; U_{2}=[20000 ; 1500000] ; U_{3}=[0 ; 50] ; U_{4}=[0 ; 10]$. The universal set for the predicted value coincides, obviously, with $U_{1}$.

For each input and for output variables, term-sets are constructed:

$$
\begin{aligned}
& A_{1}=\{\text { "small" "medium" "large" "critical" }\}=\{\mathrm{S}, \mathrm{M}, \mathrm{L}, \mathrm{C}\} ; \\
& A_{2}=\{\text { "small" "medium" "large" }\}=\{\mathrm{S}, \mathrm{M}, \mathrm{L}\} ; \\
& A_{3}=\{\text { "small" "medium" "large" }\}=\{\mathrm{S}, \mathrm{M}, C\} ; \\
& A_{4}=\{\text { "short"" medium", "long lasting" }\}=\{\mathrm{S}, \mathrm{M}, \mathrm{L}\} ; \\
& D=\{\text { "small" "medium" "large" "critical" }\}=\{\mathrm{S}, \mathrm{M}, \mathrm{L}, \mathrm{C}\}
\end{aligned}
$$

Based on the information provided by the expert, the following membership functions are constructed for the terms of input and output variables 


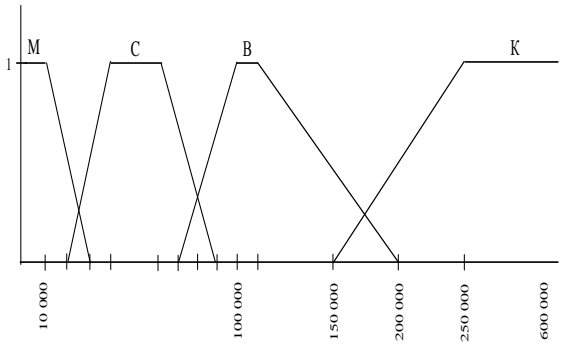

Figure 1. Membership function of linguistic variable "balance"

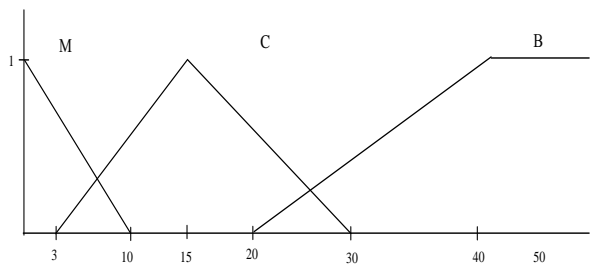

Figure 3. Membership function of linguistic variable "margin"

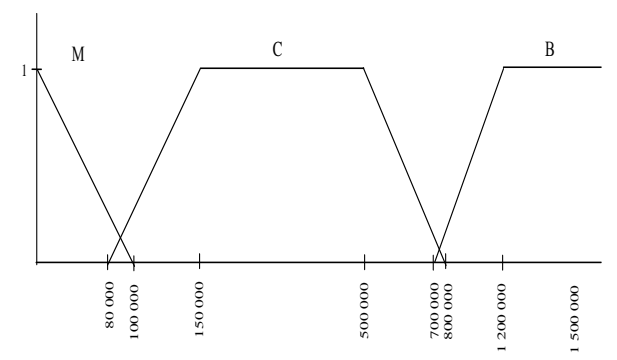

Figure 2. Membership function of linguistic variable "new purchases"

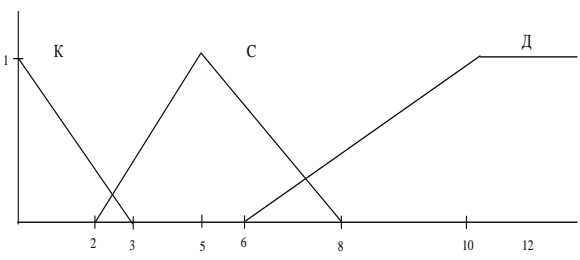

Figure 4. Membership function of linguistic variable "the duration"

The next step is to build a fuzzy knowledge base:

Table 2. The basis of the fuzzy knowledge of the problem

\begin{tabular}{|c|c|c|c|c|c|c|}
\hline \multirow{2}{*}{$\begin{array}{l}\text { Incoming } \\
\text { combination } \\
\text { number } \\
\text { (logical } \\
\text { rule) }\end{array}$} & \multicolumn{4}{|c|}{ Input variables } & \multirow{2}{*}{$\begin{array}{r}\text { Weight } \\
\qquad w\end{array}$} & \multirow{2}{*}{$\begin{array}{r}\begin{array}{r}\text { Output } \\
\text { variable }\end{array} \\
y \\
y\end{array}$} \\
\hline & $x_{1}$ & $x$ & $x$ & $x_{4}$ & & \\
\hline 11 & $M$ & $M$ & $\mathrm{M}$ & K & 1 & \multirow{11}{*}{$d_{1}$} \\
\hline 12 & B & $\mathrm{N}$ & $M$ & $\mathrm{C}$ & 0,9 & \\
\hline 13 & B & $\mathrm{M}$ & $\mathrm{M}$ & Д & 1 & \\
\hline 14 & $\mathrm{~K}$ & $\mathrm{M}$ & $M$ & $\mathrm{C}$ & 1 & \\
\hline 15 & $\mathrm{M}$ & $\mathrm{M}$ & $\mathrm{B}$ & Д & 0,7 & \\
\hline 16 & $\mathrm{M}$ & c & B & $\mathrm{C}$ & 0,7 & \\
\hline 17 & $\mathrm{C}$ & $\mathrm{M}$ & $\mathrm{C}$ & $\mathrm{C}$ & 0,8 & \\
\hline 18 & $\mathrm{C}$ & $\mathrm{M}$ & $\mathrm{C}$ & Д & 0,8 & \\
\hline 19 & $\mathrm{C}$ & c & $\mathrm{C}$ & $\mathrm{C}$ & 0,7 & \\
\hline 20 & B & $\mathrm{M}$ & C & Д & 0,9 & \\
\hline 21 & B & $\mathrm{N}$ & $\mathrm{B}$ & Д & 0,5 & \\
\hline 23 & $\mathrm{C}$ & $\mathrm{M}$ & $\mathrm{B}$ & Д & 1 & \multirow{6}{*}{$d_{2}$} \\
\hline 24 & $\mathrm{M}$ & c & C & $\mathrm{C}$ & 1 & \\
\hline 25 & $\mathrm{M}$ & $\mathrm{B}$ & $\mathrm{B}$ & $\mathrm{C}$ & 0,8 & \\
\hline 26 & $\mathrm{C}$ & $\mathrm{C}$ & $\mathrm{M}$ & $\mathrm{C}$ & 0,8 & \\
\hline 27 & $\mathrm{C}$ & $\mathrm{B}$ & $\mathrm{M}$ & $\mathrm{B}$ & 0,7 & \\
\hline 28 & $\mathrm{C}$ & B & C & $\mathrm{C}$ & 0,7 & \\
\hline 29 & $\mathrm{~B}$ & $\mathrm{C}$ & $\mathrm{C}$ & $\mathrm{C}$ & 0,7 & \multirow{7}{*}{$d_{3}$} \\
\hline 30 & B & C & $\mathrm{C}$ & Д & 0,5 & \\
\hline 31 & B & C & B & Д & 0,3 & \\
\hline 32 & K & $\mathrm{C}$ & B & Д & 0,8 & \\
\hline 33 & $\mathrm{M}$ & B & $\mathrm{C}$ & $\mathrm{C}$ & 0,9 & \\
\hline 34 & $\mathrm{M}$ & $\mathrm{B}$ & $\mathrm{C}$ & K & 1 & \\
\hline 35 & $\mathrm{C}$ & $\mathrm{B}$ & $\mathrm{M}$ & $\mathrm{K}$ & 1 & \\
\hline
\end{tabular}




\begin{tabular}{|c|c|c|c|c|c|c|}
\hline 36 & C & B & C & Д & 0,8 & \multirow{6}{*}{$d_{4}$} \\
\hline 37 & $\mathrm{M}$ & B & $\mathrm{B}$ & $\mathrm{C}$ & 0,8 & \\
\hline 38 & $\mathrm{M}$ & B & B & Д & 0,9 & \\
\hline 39 & $\mathrm{C}$ & B & $\mathrm{B}$ & $\mathrm{C}$ & 0,9 & \\
\hline 40 & $\mathrm{C}$ & B & $\mathrm{B}$ & Д & 1 & \\
\hline 41 & $B$ & B & $\mathrm{B}$ & Д & 1 & \\
\hline
\end{tabular}

The following calculations were made for the trading company data for the 2011 sales season $x_{1}{ }^{*}=80000 ; x_{2}{ }^{*}=36000 ; x_{3}{ }^{*}=22 ; x_{4}{ }^{*}=9$. In this case, the variable $x_{1}$ refers to the terms "medium" (with the degree of affiliation $\mu(x)=1-\frac{1}{30000}(x-60000)$ ) or "high" (with the degree of affiliation $\left.\mu(x)=\frac{1}{30000}(x-70000)\right) ; x_{2}$ - the term "small" (with the degree of belonging $\left.\mu(x)=1-\frac{1}{100000} x\right) ;-$ to the terms "average" (with degree of affiliation) or "high" (with degree of affiliation); $x_{3}$ - to the term "long-term" (with the degree of belonging $\mu(x)=\frac{1}{4}(x-6)$ ). By simple comparison it is easy to see that the active rules will be rules 18, 20, 21 (lead to the output $d_{1}$ ) and 23 (leads to the output $d_{2}$ ).

The quantitative value of the output value (the result of defuzzification) was calculated by the method of the center of gravity (16). Finally, the value of the forecast value of the balance of the commodity mass $y^{*}=\frac{353865180}{13588,5} \square 26041,5$ is equal to that which is sufficiently close to the real balance of the goods 23200 by the end of the 2016 season, namely US dollars.

It should be noted that the predicted values can be more closely approximated to the actual observed (taking into account data for several previous years) by reviewing the established weight coefficients, adjusting membership functions, etc. You can also increase the number of input quantities. However, with their too large numbers, the construction of a fuzzy knowledge base about the unknown dependence becomes a difficult task. This is due to the fact that in the memory of the average statistician at the same time can hold no more than $7 \pm 2$ the notions-signs. In such cases, it is expedient to carry out the classification of input variables and, in accordance with it, construct a derivation tree that defines the system of embedded statements in each other $[1,7]$.

One can propose a different approach to processing large volumes of fuzzy data under conditions of incomplete certainty of the vector of input variables (primary characteristics). The essence of the approach is based on conducting a simulation of the behavior of the investigated system and an expert assessment of the addition of the existing knowledge base to the new informative data and the establishment of the vector of input characteristics. Obviously, such an approach is iterative and it is necessary to take care of the convergence of the calculation process to achieve the goal with minimal cost and limited error.

When dealing with non-physical data in artificial intelligence problems, the construction of recognition systems, expert systems, medical and parametric diagnostics, the creation of logical-linguistic models, the most successfully adapted declarative programming languages, which in the language of logical statements and functional-logical dependencies provide the opportunity to describe the problem with fuzzy formulated data and obtaining solutions in the form of logical sequences, new functional dependences or probabilistic characteristics with definite mathematical By hope and dispersion of the input sign. Ultimately, the initial vector of primary attributes should be refined, which will ensure reliable processing of fuzzy data.

Therefore, the processing of incomplete or unclear information is, on the one hand, the application of the theory of blurry logic (in particular, the theory of fuzzy sets and measures) and the construction of logic trees or, on the other hand, the formation of logical rules from the functional-logical dependencies with indeterminate variables, which can take both deterministic and probabilistic values [11-19]. In the process of processing a priori information and selecting appropriate criteria of likelihood, you can replenish the insufficient data, providing the formation of new knowledge.

Obviously, for implementing the described approach to calculating the value of information, it is advisable to use declarative programming languages (Lisp, Prolog or their modifications depending on a 
specific objective problem) [1], which are most successfully adapted for the functions of the form (5), (6). These languages can be both analytical and descriptive (functional, logic rules, fuzzy sets), which allows solving problems associated with qualitative recognition and analysis of objects of complex structure (handwriting recognition, handwriting, psychophysiological state of a person, construction and analysis of storage, processing, information security, automated theorizing, environmental monitoring and decision-making) and implementation of the target functions relevant to a specific applied or scientific task.

IV. Conclusions. Approaches to the processing of fuzzy information under conditions of incomplete definition of the vector of input characteristics based on the theory of fuzzy sets and fuzzy measures, construction of membership functions and application of declarative programming languages are proposed.

The further development of the proposed approaches can be achieved by conducting specific statistical studies related to the need to assess the quantity and value of information based on a figurative approach.

The proposed approach is advisable to use in applied problems, where the mathematical description is difficult or completely impossible. This approach will contribute to the development, in fact, of the methods of recognition theory and identification, and the theory of information and coding.

\section{References}

1. Zaiats V.M., Zaiats M.M. Logical and functional programming. Tutorial. Grief of Ministry of Education and Science of Ukraine (list №1 / 11-16135 for 13 October 2014). Kamyanets-Podilsky: "Ruta". 2016. ISBN 978-617-738-138-8.

2. Erich Gamma, Richard Helm, Ralih Johnson, John Vlissides. Wzorce projektowe. Warszawa, Hellion, $2010.376 \mathrm{p}$

3. Zaiats V.M., Rybytska O. M The hidden possibilities of mathematics for the statistical processing of information. Materials International scientific and technical conf. "System Analysis and Information Technologies" (SAIT-2013), May 27-31, 2013, NTUU "KPI". Kiev: 2013. P. 317-318.

4. Novak V., Perfiliev I., Mochkorzh. I. Mathematical Principles of Fuzzy Logic. M: Fiz. mat. lit, 2006.

5. Zadeh L.A. Outline of a new approach to the analysis jf complex systems and decision processes. IEEE. Trans. Syst. Man and Cybern. 1973. Vol. 3, N 1. C. 28-44.

6. Konysheva L.K., Nazarov D.M. Fundamentals of the theory of fuzzy sets. M: Peter 2011. 190 p.

7. Syavalko M. Mathematics of hidden possibilities. Ostrog: Publishing "Ostroh Academy", 2011.

8. Turksen I.B. Fuzzy expert systems. Ed. M. Zheleny. Petersburg: Peter. 2002. 1120 p.

9. Rothstein O.P., Rottshtein O.P., Zhupanova M.O., Sheverda V.M. Differential diagnosis of coronary heart disease on the basis of fuzzy logic. Herald VPI. 1994. №3, pp.32 -38.

10. Zimmermann H.J. Fuzzy Set Theory and it's Applications. Kluner Academic Publishers, Dordrecht, Boston, MA, $2^{\text {nd }}$, 1991.

11. V.M. Zaiats, "Constraction and analises of model descrete oscillation systems", Cybernetics and Systems Analysis, vol. 2,, Kiev, NAS of Ukraine, 2000, pp. 161-165.

12. V.M. Zaiats, The Models Descrete Oscillation Systems, Computer Tegnology of Print, Lviv,UAP, 2011, pp.37-39.

13. J. Vlach and K. Singhall. Computer Methods for Circuit Analysis and Design, New York, VNRC, 1980, 560 p.

14. L. Feldman, A. Petrenko and O. Dmitrieva. Numerical Methods in informatic, Kiev, BHV, 2006, 480 p.

15. G. Holl and J.M. Watt. Modern Numerical Methods for Ordinary Differential Equations,. Clarendon press, Oxford, $1979,312 \mathrm{p}$.

16. D. Forsait, H.Malkom, K. Mouler. Computer Methods of Mathematics Calculations. Moscow, Peace,1980, 282.p.

17. X. Shtetter. Analises Descretization for Original Differencial Equations. Moskow, Peace,1978, 462 p.

18. V.M. Zaiats. Discrete Models of Oscillatory Systems for the Analysis of their Dynamics. Lviv, UAP, 2011, 284 p.

19. V.M. Zaiats, Methods, Algorithms and Software for Simulation and Analysis of the Dynamics of Complex Objects and Systems Based on Discrete Models. Lviv: New World, 2009, 400 p.

\section{Список бібліографічного опису}

1. Заяць В.М., Заяць М.М. Логічне та функиіональне програмування. Навчальний посібник. Гриф надало Міністерство освіти і науки України (лист №1 / 11-16135 за 13 жовтня 2014 року). Кам’янець-Подільський: «Рута». 2016. ISBN 978-617-738-138-8. 4.

2. Еріх Гамма, Річард Хелм, Раліх Джонсон, Джон Віссайдс. Шаблони проектів. Варшава, Геліон, 2010. 376 с.

3. Заяць В. М., Рибицька О. М. Приховані можливості математики для статистичної обробки інформації. Матеріали Міжнародна науково-технічна конф. "Системний аналіз та інформаційні технології" (SAIT-2013), 27-31 травня 2013 р., НТУУ "КПІ". Київ. 2013. С. 317-318.

4. Новак В., Перфілієв, І., Мочкорж І. Математичні засади нечіткої логіки. М: Фізмаліт, 2006.

5. Zadeh L.A. Outline of a new approach to the analysis jf complex systems and decision processes. IEEE. Trans. Syst. Man and Cybern. 1973. Vol. 3, N 1. С. 28-44.

6. Конишева Л.К., Назаров Д.М. Основи теорії нечітких множин. М: Пітер 2011. 190 с.

7. Сявалко М. Математика прихованих можливостей. Острог: Видавництво НУ «Острозька академія». 2011. 
32 Науковий журнал "Комп’ютерно-інтегровані технології: освіта, наука, виробництво" Луцьк, 2020. Випуск № 38

8. Турксен І.Б. Нечіткі експертні системи. За ред. М. Желены. Петербург: Пітер. 2002. 1120 с.

9. Ротштейн О. П., Жупанова М.О., Шеверда В.М. Диференциіальна діагностика ішемічної хвороби серия на основі нечіткої логіки. Вісник ВПІ. 1994. №3. С.32 -38.

10. Zimmermann H.J. Fuzzy Set Theory and it's Applications. Kluner Academic Publishers, Dordrecht, Boston, MA, 1991.

11. В.М. Заяць. Побудова та аналіз моделей конкретних коливальних систем. Кібернетика та системний аналіз, т. 2, Київ, НАН України, 2000, с. 161-165.

12. В.М. Заяць Дискретні моделі коливальних систем, Комп'ютерні технології друкарства, Львів, УАД, 2011, с. $37-$ 39.

13. Дж. Влах, К. Сингал, Комп'ютерні методи аналізу та проектування ланцюгів ”, Нью-Йорк, ВНРК, 1980, 560 с.

14. Л. Фельдман, А. Петренко та О. Дмитрієва, Числові методи в інформатиці, Київ, ВНV, 2006, 480 с.

15. Г. Холл та Дж. М. Ватт, Сучасні чисельні методи звичайних диференціальних рівнянь,. Оксфорд, 1979, 312 с.

16. Д. Форсайт, Х.Малком, К. Мюллер, Комп'ютерні методи математичних обчислень, Москва, Мир, 1980, $282 . п$.

17. Х. Штеттер, Аналіз декретних оригінальних диференціальних рівнянь, Москва, Мир, 1978, 462 с.

18. В.М. Заяць. Дискретні моделі коливальних систем для аналізу їх динаміки, УАД, 2011, 284 с.

19. В.М. Заяць. Методи, алгоритми та програмне забезпечення для моделювання та аналізу динаміки складних об'єктів і систем на основі дискретних моделей. Львів, Новий Світ, 2009, 400 с.

Стаття надійшла 02 березня 2020 p. 